\title{
Inflammatory Bowel Disease and the Risk of Herpes Zoster
}

\author{
Shih-Wei Lai ${ }^{1,2}$ \\ ${ }^{1}$ College of Medicine, China Medical University, and ${ }^{2}$ Department of Family Medicine, China Medical University Hospital, Taichung, Taiwan
}

\section{To the Editor:}

Recently, one cohort study conducted by Soh et al. ${ }^{1}$ published in Gut and Liver disclosed that inflammatory bowel disease (IBD) was associated with an elevated risk of herpes zoster (adjusted hazard ratio of 1.40 in ulcerative colitis and 2.13 in Crohn's disease), which was consistent with the findings of previous studies. ${ }^{2,3}$ Some of my ideas are shared with the readers. First, the incidence of herpes zoster was higher in people with IBD than those without IBD in Soh et al.'s study (14.51 per 1,000 personyears vs 9.19 per 1,000 person-years). The attributable risk caused by IBD was 5.32 per 1,000 person-years. ${ }^{1}$ Therefore, lack of IBD may reduce the cases of herpes zoster by approximately 53 per 10,000 person-years of follow-up. Similarly, another cohort study disclosed that the incidence of herpes zoster was higher in people with chronic pancreatitis than those without chronic pancreatitis (6.22 per 1,000 person-years vs 4.63 per 1,000 person-years). ${ }^{4}$ Therefore, lack of chronic pancreatitis may reduce the cases of herpes zoster by approximately 16 per 10,000 person-years of follow-up. These results indicate that the impact of IBD on the risk of herpes zoster is higher than that of chronic pancreatitis. Second, alcohol consumption is a major cause of chronic pancreatitis. Once alcohol intake is stopped, the risk of chronic pancreatitis would potentially be decreased, and then the risk of herpes zoster would also be decreased. However, removing IBD is unlikely because IBD currently cannot be prevented or cured. Vaccinations for herpes zoster should be considered from the perspective of primary prevention. One metaanalysis disclosed that the risk of herpes zoster was significantly lower in people aged $\geq 60$ years who received the live attenuated vaccine of varicella-zoster virus than those without vaccination (risk ratio, 0.49; 95\% confidence interval, 0.43 to 0.56 ). ${ }^{5}$ Third, not all countries can afford the cost of a universal vaccination program for herpes zoster. Therefore, people who have risk factors for herpes zoster should be regarded as the first priority for receiving the herpes zoster vaccination. Soh et al.'s study high- lights that people with IBD are at high risk for herpes zoster, and these people should receive vaccinations for herpes zoster.

\section{CONFLICTS OF INTEREST}

No potential conflict of interest relevant to this article was reported.

\section{ORCID}

Shih-Wei Lai https://orcid.org/0000-0002-7420-1572

\section{REFERENCES}

1. Soh H, Chun J, Han K, et al. Increased risk of herpes zoster in young and metabolically healthy patients with inflammatory bowel disease: a nationwide population-based study. Gut Liver 2019;13:333-341.

2. Tsai SY, Yang TY, Lin CL, Tsai YH, Kuo CF, Kao CH. Increased risk of varicella zoster virus infection in inflammatory bowel disease in an Asian population: a nationwide population-based cohort study. Int J Clin Pract 2015;69:228-234.

3. Côté-Daigneault J, Bessissow T, Nicolae MV, et al. Herpes zoster incidence in inflammatory bowel disease patients: a populationbased study. Inflamm Bowel Dis 2019;25:914-918.

4. Lai SW, Lin CL, Liao KF. Chronic pancreatitis correlates with increased risk of herpes zoster in a population-based retrospective cohort study. J Hepatobiliary Pancreat Sci 2018;25:412-417.

5. Gagliardi AM, Andriolo BN, Torloni MR, Soares BG. Vaccines for preventing herpes zoster in older adults. Cochrane Database Syst Rev 2016;3:CD008858.

\footnotetext{
Correspondence to: Shih-Wei Lai

Department of Family Medicine, China Medical University Hospital, No 2, Yu-De Road, Taichung 404, Taiwan

Tel: +886-4-2205-2121, Fax: +886-4-2203-3986, E-mail: wei@mail.cmuh.org.tw
}

Received on April 27, 2019. Revised on May 13, 2019. Accepted on May 17, 2019. pISSN 1976-2283 eISSN 2005-1212 https://doi.org/10.5009/gnl19141

@ This is an Open Access article distributed under the terms of the Creative Commons Attribution Non-Commercial License (http://creativecommons.org/licenses/by-nc/4.0) which permits unrestricted non-commercial use, distribution, and reproduction in any medium, provided the original work is properly cited. 